\title{
Fluorescence in situ hybridization in diluted and flow cytometrically sorted boar spermatozoa using specific DNA direct probes labelled by nick translation
}

\author{
I. Parrilla ${ }^{1}$, J. M. Vázquez ${ }^{1}$, M. Oliver-Bonet ${ }^{2}$, J. Navarro ${ }^{2}$, J. Yelamos ${ }^{3}$, \\ J. Roca ${ }^{1}$ and E. A. Martínez ${ }^{1}$ \\ ${ }^{1}$ Department of Animal Medicine and Surgery, University of Murcia, 30071 Murcia, Spain; \\ ${ }^{2}$ Department of Biology, University of Barcelona, Bellaterra, Barcelona, Spain; and \\ ${ }^{3}$ Transplantation Unit, Department of Surgery, Hospital 'Virgen de la Arrixaca', Murcia, Spain
}

\begin{abstract}
Successful evaluation of $\mathrm{X}$ - and Y-chromosome-bearing sperm separation technology using flow cytometry-cell sorter is of great importance. Fluorescence in situ hybridization (FISH), which allows for the detection of specific nucleic acid sequences on morphologically preserved spermatozoa, is an ideal method for quantitatively and qualitatively assessing the purity of sorted sperm samples. In this study specific pig DNA direct probes for small regions of chromosomes 1 and $\mathrm{Y}$ were used. Chromosome 1 was labelled in green and used as internal control to detect a lack of hybridization, whereas chromosome $Y$ was labelled in red. Nick translation was used as the labelling method for the preparation of these probes. Spermatozoa, unsorted and sorted for high and low Y-chromosome purity from ejaculates of five boars, were fixed on slides and two-colour direct FISH was performed
\end{abstract}

for chromosomes 1 and Y. About 500 non-sorted and 200 sorted spermatozoa per sample were scored. The proportion of Y-chromosome-bearing spermatozoa was determined by the presence of a red fluorescent signal on the sperm head and the proportion of X-chromosomebearing spermatozoa was determined by subtraction. The efficiency of the hybridization procedure was established as near $98 \%$ on sorted and unsorted samples. The results of this study confirm that direct FISH using specific pig DNA probes labelled by nick translation provides a useful tool for laboratory validation of sperm separation by flow sorting technology. Moreover, the ease of nick translation and the quality of the fluorescent signal obtained using this method makes this procedure the most appropriate method for labelling pig DNA probes to be used for direct FISH on pig spermatozoa.

\section{Introduction}

The sex of offspring can be predetermined with variable precision using a flow cytometric sperm sorting technique. This method is based on the differential amount of DNA present in X- and Y-chromosomebearing spermatozoa (Johnson and Pinkel, 1986). This difference can be measured by the use of a modified flow cytometer-cell sorter, which is able to sort into populations enriched for X- or Y-chromosome-bearing spermatozoa with a high percentage of purity (Johnson et al., 1989; Johnson, 1991, 1997; Seidel and Garner, 2002). The current production rate using this technology is $10-15 \times 10^{6} \mathrm{X}$ - and $\mathrm{Y}$-chromosome-sorted spermatozoa per hour (Johnson and Welch, 1999).

Determination of the resulting sex ratio before inseminating the sorted spermatozoa is essential to make this reproductive technique economically feasible. The sex of the offspring depends on the purity of the sorted

Email: parrilla@um.es spermatozoa in terms of X:Y-chromosome sperm ratio and, in turn, the purity of the sorted spermatozoa depends on the width of the sorting area setting (Johnson, 1997; Seidel and Garner, 2002). Unfortunately, the production rate also depends on the sorting windows; increasing the size of the sort windows by $15 \%$ allows about a $20 \%$ increase in the rate of sorting spermatozoa to be achieved; however, the purity of the sorted population defined as the percentage of spermatozoa bearing the selected chromosome ( $\mathrm{X}$ or $\mathrm{Y}$ ) decreases by $10 \%$ (Johnson, 1997). Thus, the purity of the sorted spermatozoa decreases as the production rate increases during sorting. Although a high purity with a low production rate can be selected when sorted spermatozoa are used for IVF or intracytoplasmic sperm injection, a high production rate is needed for deep intrauterine insemination with sorted spermatozoa in sows (Vazquez et al., 2003). Therefore, the use of a wide sorting window is necessary during the sorting with consequent detrimental effect on the purity of the sperm population. 
Since the introduction of sperm-sexing technology, several laboratory validation methods have been developed for verifying the purity of sorted X- and Ychromosome bearing spermatozoa. The sort re-analysis method described by Johnson et al. $(1987,1989)$ involves the re-analysis of spermatozoa that have already been sorted by flow cytometry. As this method relies on the same instrumentation that produced the original sperm separation, it is not truly independent. Besides, when the difference in DNA content between $\mathrm{X}$ - and $\mathrm{Y}$ chromosomes is small, as in human spermatozoa, sort-reanalysis cannot be performed with the required accuracy (Johnson et al., 1993; Fugger et al., 1998).

Molecular biology offers various techniques for assessing the effectiveness of $\mathrm{X}$ - and $\mathrm{Y}$-chromosome separation. PCR DNA amplification of single cells has been used to assess the purity of the sorted spermatozoa (Welch et al., 1995). However, the labour required to conduct PCR of single cells likely prohibits its use for the routine monitoring of sorted spermatozoa.

Fluorescence in situ hybridization (FISH) has also been used to analyse sorted spermatozoa. Kawarasaki et al. (1998) showed that two-colour FISH using a combination of DNA probes specific for chromosomes $Y$ and 1 was useful for estimating the purity of $X$ and $Y$ sperm cells sorted by flow cytometry. This method offers the opportunity to use an independent technique for validating sorted sperm samples quantitatively and qualitatively (Welch and Johnson, 1999).

The most important reagents on a FISH procedure are the fluorescent DNA probes. After or during DNA amplification steps by PCR, specific DNA must be labelled by incorporating fluorescent nucleotides. It is important to use a labelling method that allows the production of probes with good specificity that are easy to visualize to produce optimal hybridization results. The type of probe and labelling method should be chosen according to the sensitivity requirements of the situation.

The FISH technique has been performed on bull (Hassanane et al., 1999; Piumi et al., 2001) and boar spermatozoa (Kawarasaki et al., 1995, 1996), and boar and cattle sperm flow sorting has also been evaluated by indirect FISH probes (Kawarasaki et al., 1998; Rens et al., 2001). However, no results have been described
Nick translation reaction is an enzymatic labelling method (Rigby et al., 1977) used for incorporating nucleotide analogues (Langer et al., 1981). This method is frequently used for labelling DNA probes on human cytogenetical analysis. Piumi et al. (2001) used this technique to prepare an indirect fluorescent probe for $\mathrm{X}$ chromosome detection on bovine spermatozoa. In this procedure one strand of the double-stranded DNA is nicked with deoxyribonuclease (DNase I). Subsequently, a 5'-3' exonuclease, DNA polymerase I, extends the nicks to gaps and the polymerase replaces the excised nucleotides with fluorescent-labelled substitutes on the basis of the complementary strand.

The aim of the present study was to determine an easy procedure for direct FISH on boar spermatozoa using nick translation-labelled pig DNA direct probes specific for small regions of chromosomes 1 and $\mathrm{Y}$. The efficiency of the nick translation reaction was evaluated by performing a FISH assay on pig spermatozoa that were unsorted and sorted for high and low purity. The advantages and disadvantages of this procedure were analysed.

\section{Materials and Methods}

All reagents used in this study were provided by SigmaAldrich Co. (Alcobendas, Madrid), unless otherwise stated.

Preparation of DNA direct probes labelled by nick translation

PCR amplification of 1- and Y-chromosome specific fragments. Pig chromosomes 1 - and $\mathrm{Y}$-specific primers were designed according to oligonucleotide sequences described by Rubeš et al. (1999). PCR amplification resulted in products of $377 \mathrm{bp}$ and $244 \mathrm{bp}$ for the $\mathrm{Y}$ and 1-chromosome specific fragments, respectively. The sequence for 1 chromosome (X51555) is 313 nucleotides in length with a copy number of $2 n=3000-6000$ (Jantsch, 1989), whereas the sequence for $Y$ chromosome (X12696) is 3832 nucleotides in length with no marked internal repetitions (McGraw et al., 1988).

Oligonucleotide sequences were as follows:

\section{Chromosome $1\left[\begin{array}{l}\text { Forward: 5'-GTT GCA CTT TCA CGG ACG CAG C-3' } \\ \text { Reverse: 5'-CTA GCC CAT TGC TCG CCA TAG C-3' }\end{array}\right.$ \\ Chromosome Y $\left[\begin{array}{l}\text { Forward: 5'-AAT CCA CCA TAC CTC ATG GAC C-3' } \\ \text { Reverse: 5'-TTT CTC CTG TAT CCT CCT GC-3' }\end{array}\right.$}

using direct probes for evaluating the purity of $\mathrm{X}$ - and Y-chromosome sorted spermatozoa.
All reagents were thawed in advance and kept on ice before use in the PCR reaction. The master mix was prepared by mixing $0.4 \mu \mathrm{l}$ of a mixture of 4 dNTPs 
(dTTP, dATP, dGTP and dCTP each at $2 \mathrm{mmol} \mathrm{I}^{-1}$ ),

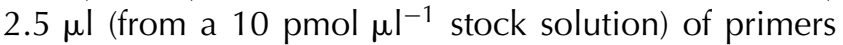
for chromosomes 1 and $Y, 5 \mu l$ of pig genomic DNA containing 10-100 ng of DNA; $5 \mu$ l of $10 \times$ PCR buffer $\left(100 \mathrm{mmol}\right.$ Tris- $\mathrm{HCl} \mathrm{I}^{-1}, \mathrm{pH} 8.3$ at $25^{\circ} \mathrm{C} ; 500 \mathrm{mmol}$ $\mathrm{KCl} \mathrm{I}-1 ; 15 \mathrm{mmol} \mathrm{MgCl}_{2} \mathrm{I}^{-1} ; 0.01 \%(\mathrm{w} / \mathrm{v})$ gelatine) and $0.5 \mu \mathrm{l}$ of $5 \mathrm{U}$ Taq DNA polymerase $\mu \mathrm{I}^{-1}$. The volume reaction was made up to $50 \mu \mathrm{l}$ with water. Amplification cycles were performed in a thermocycler (Personal Master Cycler, Eppendorf) and consisted of a first denaturation step before the first cycle at $95^{\circ} \mathrm{C}$ for $5 \mathrm{~min}$, followed by 35 cycles of the following programme: denaturation at $95^{\circ} \mathrm{C}$ for $15 \mathrm{~s}$, annealing at $60^{\circ} \mathrm{C}$ for $1 \mathrm{~min}$ and extension at $72^{\circ} \mathrm{C}$ for $15 \mathrm{~s}$. Finally, an elongation step for $7 \mathrm{~min}$ at $72^{\circ} \mathrm{C}$ was performed after the last cycle.

Ten microlitre samples of each PCR product were subjected to electrophoresis in $1 \%(\mathrm{w} / \mathrm{v})$ agarose gels. Amplified products were stained with ethidium bromide and visualized, and then photographed under UV light. The remainder of the PCR product was precipitated with ethanol and sodium acetate before determining the final concentration of amplified DNA.

\section{Nick translation reaction}

The specific DNA sequences of 1 and $Y$ chromosomes amplified by PCR were used as DNA templates and were labelled using the modified deoxyuridine triphosphates (dUTP), Cy3-dUTP (Amersham Pharmacia Biotech Europe $\mathrm{GmbH}$, Barcelona) which provides a red fluorescent signal for chromosome $Y$, and Alexa Fluor 488-5-dUTP (Molecular Probes Europe BV) which provides green fluorescence signal for chromosome 1.

All chemicals used in this reaction were purchased from Amersham Pharmacia Biotech Europe GmbH (Barcelona). The nick translation reaction (Nick Translation kit; N 5500 ${ }^{\circledR}$, Amersham Pharmacia Biotech) was performed by adding $15 \mu \mathrm{l}$ of PCR product containing $1 \mu \mathrm{g}$ of template DNA to a microcentrifuge tube containing $20 \mu \mathrm{l}$ of nucleotide buffer $\left(14 \mu \mathrm{mol} \mathrm{I} \mathrm{I}^{-1}\right.$ for dATP, dGTP, and dTTp and $4 \mu \mathrm{mol} \mathrm{I}^{-1}$ for dCTP), $1 \mu \mathrm{l}$ of fluorescent labelled nucleotide $\left(1 \mathrm{mmol} \mathrm{I}{ }^{-1}\right), 10 \mu \mathrm{l}$ of enzyme mix $(0.5$ units per $\mu \mathrm{l}$ DNA polymerase 1 and $10 \mathrm{pg}$ $\mu$ l DNase I in Tris- $\mathrm{HCl} \mathrm{pH} 7.5, \mathrm{MgCl}_{2}$, glycerol and bovine serum albumin), $1 \mu \mathrm{l}$ of freshly diluted DNase I (0.002333 units of enzyme); the final volume was adjusted to $50 \mu \mathrm{l}$ with water. An incubation step of $4 \mathrm{~h}$ and $15 \mathrm{~min}$ was needed to complete the reaction. After

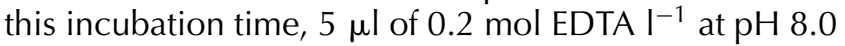
was added to stop the reaction.

\section{Flow cytometric sperm sorting}

Semen samples were collected from five fertile boars and diluted on Beltsville thawing solution (BTS) $\left(205.0 \mathrm{mmol}\right.$ glucose $\mathrm{I}^{-1}, 20.39 \mathrm{mmol} \mathrm{NaCl} \mathrm{I}^{-1}$, $5.4 \mathrm{mmol} \mathrm{KCl} \mathrm{I}{ }^{-1}, 15.01 \mathrm{mmol} \mathrm{NaHCO}_{3} \mathrm{I}^{-1}$ and

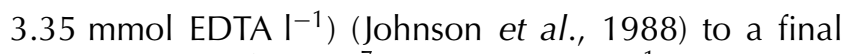
concentration of $3 \times 10^{7}$ spermatozoa $\mathrm{ml}^{-1}$.

Sorted spermatozoa were obtained following the general procedure described by Johnson et al. (1989). Briefly, $50 \mathrm{ml}$ of diluted spermatozoa was stained with Hoechst-33342 $\left(9 \mu \mathrm{mol} \mathrm{I}^{-1}\right)$ and incubated for $1 \mathrm{~h}$ at $35^{\circ} \mathrm{C}$. After $15 \mathrm{~min}$ at room temperature $\left(25^{\circ} \mathrm{C}\right)$, stained spermatozoa were sorted with a modified EPICS Altra Flow Sorter (Coulter Corporation, Miami, FL) operating at 42 p.s.i. and with a power laser of $160 \mathrm{~mW}$. Spermatozoa were sorted for Y-chromosome-bearing spermatozoa according to the criteria of high purity or low purity by adjusting the size of the sort window. A wide sort window allows a high production rate with a low purity, whereas a narrow sort window allows a low production rate but with a high purity. Control samples consisted of unsorted spermatozoa from the same boars.

\section{Fluorescence in situ hybridization}

Direct FISH was performed on sorted and non-sorted boar spermatozoa. The specificity of the probes was evaluated using metaphase spreads from pig lymphocytes.

Preparation of spermatozoa. Five millilitres of unsorted $\left(3 \times 10^{7}\right.$ spermatozoa $\left.\mathrm{ml}^{-1}\right)$ or $10-15 \mathrm{ml}$ of sorted spermatozoa $\left(0.5 \times 10^{6}\right.$ spermatozoa $\left.\mathrm{ml}^{-1}\right)$ were centrifuged for $5 \mathrm{~min}$ at $1200 \mathrm{~g}$ and resuspended in a $\mathrm{KCl}$ hypotonic solution $\left(75 \mathrm{mmol} \mathrm{I}^{-1}\right.$ ) providing a final volume of $6 \mathrm{ml}$. This step was repeated at least twice. Subsequently, the supernatant was discarded and the pellet was resuspended in fresh, cold fixative (methanol:glacial acetic acid $3: 1$ ), bringing the sperm suspension to a volume of 4$6 \mathrm{ml}$ (depending on the sperm concentration). The fixed sperm suspension was spread on a clean glass slide and air-dried.

Before hybridization, the slides were washed in $2 \times$ saline-sodium citrate buffer (SSC) to remove excess fixative, dehydrated by passing through a series of ethanol $(70 \% ; 85 \% ; 100 \%)$ and air-dried. Subsequently, the slides were incubated for $15 \mathrm{~min}$ at $37^{\circ} \mathrm{C}$ in a $5 \mathrm{mmol}$ dithiothreitol (DTT) $\mathrm{I}^{-1}$ solution $(\mathrm{pH} 7.4)$ to reduce the protamine disulphide bonds and, thus, to produce the decondensation of sperm nuclei. For boar D, it was necessary to repeat this sperm decondensation step for a further $10 \mathrm{~min}$. The slides were washed again in $2 \times \mathrm{SSC}$, dehydrated by passing through a series of ethanol and air-dried. Denaturation was carried out in $70 \%(\mathrm{v} / \mathrm{v})$ formamide $/ 2 \times \mathrm{SSC}$ solution at $75^{\circ} \mathrm{C}$ for $5 \mathrm{~min}$. Finally, the slides with sorted and unsorted spermatozoa were dehydrated again by passing through a new series of ethanol and dried at room temperature.

Preparation of metaphases. Peripheral blood was aseptically collected from the same five boars that were used to obtain sperm samples. Metaphase chromosome spreads obtained from pig lymphocyte cultures were 


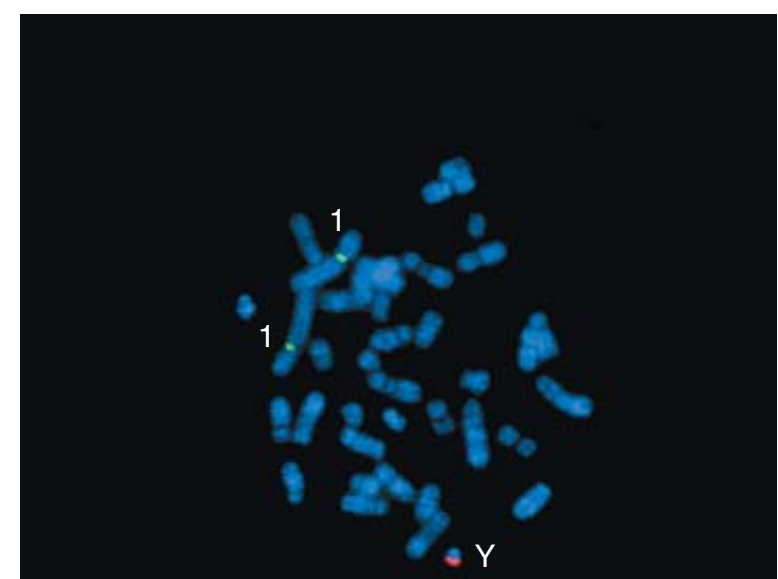

Fig. 1. Normal metaphase chromosome spreads from boar lymphocytes demonstrating hybridization signal on the 1- and Y-chromosomes (green and red, respectively) obtained with nick translation-labelled probes.

used as FISH controls. Cell suspensions were cultured using the protocol described for goat metaphases by $\mathrm{Di}$ Berardino et al. (1996) with minor modifications. Briefly, aliquots of $0.5 \mathrm{ml}$ whole blood containing $6 \times 10^{6}$ lymphocytes were added to each of five culture flasks containing $8 \mathrm{ml}$ Roswell Park Memorial Institute 1640 medium without L-glutamine (Gibco, Life Technologies, Barcelona), including $1.0 \mathrm{ml}$ fetal bovine serum, $0.1 \mathrm{ml}$ L-glutamine, $50.0 \mu \mathrm{l}$ antibiotic-antimycotic solution, and $0.1 \mathrm{ml}$ pokeweed mitogen (lectin from Phytolacca Americana, Sigma-Aldrich Co.) to stimulate mitogenetic activity. The cultures were allowed to grow for $68 \mathrm{~h}$ at $38.5^{\circ} \mathrm{C}$, and colcemid (Gibco) was added at a final concentration of $0.1 \mu \mathrm{g} \mathrm{ml}^{-1}$ at $15 \mathrm{~min}$ before harvesting. Harvested cells were treated with hypotonic solution $\left(75 \mathrm{mmol} \mathrm{KCl}^{-1}\right.$ ) and fixed in methanol:acetic acid (3:1). After fixation, the metaphases were dropped on to clean microscope slides and air-dried.

Denaturation processing of these slides was as follows: the slides were first placed in a Coplin jar with $2 \times$ SSC for 1 h. Subsequently, $100 \mu$ l of RNase solution $\left(100 \mu \mathrm{g} \mathrm{ml}^{-1}\right.$ in $\left.2 \times \mathrm{SSC}\right)$ was deposited on to the slide and covered with a $24 \mathrm{~mm} \times 36 \mathrm{~mm}$ cover glass and incubated at $37^{\circ} \mathrm{C}$ for $1 \mathrm{~h}$. The slides were then washed in $2 \times \mathrm{SSC}$ at room temperature for $5 \mathrm{~min}$, and pepsinized $(5 \mu \mathrm{l}$ of $0.01 \%(\mathrm{w} / \mathrm{v})$ of pepsin in $50 \mu \mathrm{l}$ of $10 \mathrm{mmol} \mathrm{HCl} \mathrm{I}{ }^{-1}$ ) for $5 \mathrm{~min}$. Treatment after fixation was as follows: $5 \mathrm{~min}$ in PBS containing $50 \mathrm{mmol} \mathrm{MgCl}_{2} \mathrm{I}^{-1} ; 10 \mathrm{~min}$ in $1 \%(\mathrm{v} / \mathrm{v})$ formaldehyde solution in $50 \mathrm{mmol}$ PBS- $\mathrm{MgCl}_{2} \mathrm{I}^{-1}$ and finally $5 \mathrm{~min}$ in PBS. After a dehydration step the slides were air-dried and observed by phase-contrast microscopy $(\times 400)$. Denaturation solution $(70 \%(\mathrm{v} / \mathrm{v})$ deionized formamide, $2 \times$ SSC, adjusted to $\mathrm{pH} 7.0$ ) was freshly prepared and heated just before use. Slides were denatured for $5 \mathrm{~min}$ at $75^{\circ} \mathrm{C}$, dehydrated in a new ethanol series and air-dried.

\section{Hybridization and detection}

Three microlitres of $\mathrm{Y}$-chromosome labelled probe and $3 \mu \mathrm{l}$ of 1 -chromosome labelled probe were precipitated by cold ethanol and sodium acetate for $3 \mathrm{~h}$ at $-80^{\circ} \mathrm{C}$ or overnight at $-20^{\circ} \mathrm{C}$. After precipitation, probes were washed with $70 \%(\mathrm{v} / \mathrm{v})$ ethanol, and centrifuged at $23000 \mathrm{~g}$ for $30 \mathrm{~min}$. DNA pellets were resuspended in $10 \mu \mathrm{l}$ Hybridization Solution ${ }^{\circledR}$. This hybridization mixture was denatured at $75^{\circ} \mathrm{C}$ for $5 \mathrm{~min}$ and then dropped on to the previously denatured slides and finally covered with a coverslip. The slides were sealed with rubber cement and placed in a dark moist chamber at $37^{\circ} \mathrm{C}$ for $72 \mathrm{~h}$. After hybridization, slides were washed in $0.4 \times \mathrm{SSC}$ solution at $75^{\circ} \mathrm{C}$ for $2 \mathrm{~min}$, followed by a further wash in $2 \times \mathrm{SSC} / 0.1 \%(\mathrm{v} / \mathrm{v})$ Tween 20 at room temperature for $2 \mathrm{~min}$, dehydrated by a series of ethanol $(70 \% ; 85 \% ; 100 \%)$ and air-dried. The slides were finally counterstained with $8 \mu \mathrm{l}$ of 4',6-diamino-2phenylindole (DAPI) antifade solution.

\section{Analysis of the samples}

The slides were examined under a fluorescence microscope (Leica DMRB Fluo. equipped with a DAPI, fluorescence isothiocyanate and Texas Red filters, Heerbrugg). A total of 2500 non-sorted spermatozoa, 2000 sorted spermatozoa (for low and high sorted purity) and 50 metaphase plates were analysed. Control slides were observed and the correct localization of the fluorescent signal on the metaphase spreads was evaluated. Spermatozoa were scored only if they were intact, non-overlapped, had a clearly defined border, and had not decondensed to more than twice the size of a non-decondensed sperm head, which could produce large and sometimes fragmented FISH signals.

A $\chi^{2}$ test was used to investigate the deviation from the expected ratio 50:50 (X:Y) of the percentages of putative Y-chromosome-bearing spermatozoa for each unsorted and sorted population and to compare the percentages of spermatozoa showing signal on chromosome 1.

\section{Results}

Specific pig DNA probes for direct FISH were labelled with fluorescent nucleotides using nick translation. The time invested in performing this labelling reaction and the ease of the procedure were evaluated. The technical manipulation of the reagents was minimal and, thus, the protocol for preparing specific DNA fluorescent probes by nick translation was very easy to perform.

Control slides prepared with metaphase chromosome spreads from boar lymphocytes exhibited signals at the appropriate regions of the 1- and Y-chromosomes illustrating the high specificity of the probes for their respective complementary sequence (Fig. 1). Signal for chromosome 1 was observed on the centromeric region, 


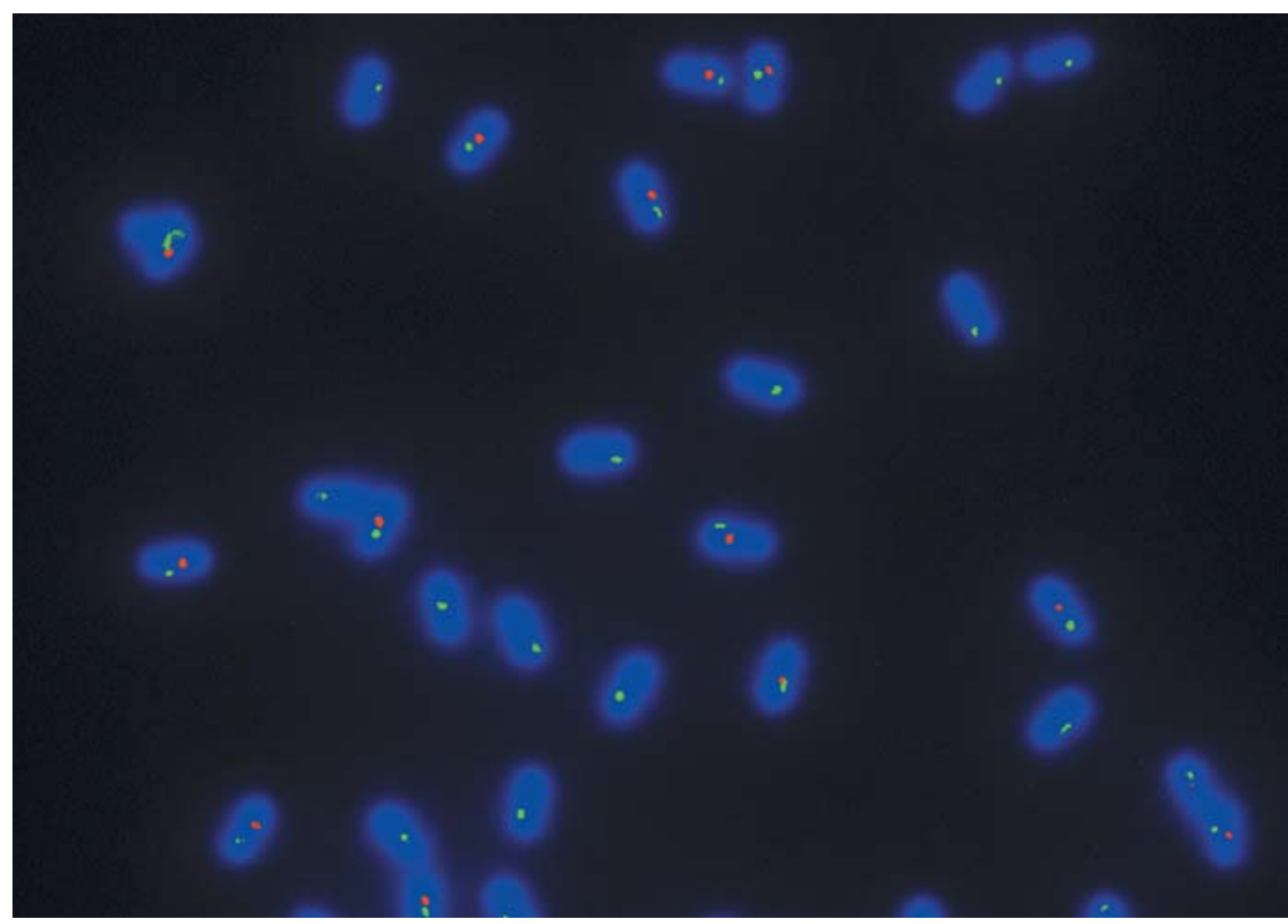

Fig. 2. Unsorted boar spermatozoa: 1- and Y-chromosomes hybridized with nick translation labelled probes. Only sperm heads with green signal were considered as X-chromosome-bearing spermatozoa.

Table 1. Percentage of X- and Y-chromosome unsorted boar spermatozoa by fluorescence in situ hybridization (FISH)

\begin{tabular}{|c|c|c|c|c|c|}
\hline Boars & Number counted & $\mathrm{Y}(\mathrm{Y}$ and 1 signals*) & $X$ (only 1 signal ${ }^{\dagger}$ ) & Without signals & $\begin{array}{c}\text { Significance } \\
\text { (deviation from 50:50) }\end{array}$ \\
\hline$A$ & 500 & 48.0 & 50.4 & 1.6 & NS \\
\hline B & 500 & 51.0 & 46.6 & 2.4 & $P<0.05$ \\
\hline C & 500 & 50.6 & 47.6 & 1.8 & NS \\
\hline$D^{\ddagger}$ & 500 & 48.2 & 49.2 & 2.6 & NS \\
\hline E & 500 & 52.8 & 46.0 & 1.2 & $P<0.05$ \\
\hline
\end{tabular}

*Spermatozoa labelled with the green and red fluorescent signals (chromosomes 1 and $\mathrm{Y}$, respectively).

${ }^{\dagger}$ Spermatozoa labelled only with the green fluorescent signal (chromosome 1).

$¥$ An additional $10 \mathrm{~min}$ decondensation treatment was necessary for this boar.

NS: not significant $(P>0.05)$.

whereas the fluorescent mark for $\mathrm{Y}$ chromosome was visible on the long arm of the chromosome.

One of the crucial steps for FISH experiments is to achieve proper nuclear decondensation, so as to obtain efficient hybridization results. In boar D, the additional 10 min decondensation treatment was necessary to obtain adequate decondensation.

The results obtained after the FISH procedure on sorted and unsorted spermatozoa are shown (Figs 2 and 3 , respectively). The green signal on chromosome 1 is clearly identifiable on the decondensed sperm heads independent of the sperm sample used. The red signal produced with the $\mathrm{Y}$ probe obtained by nick translation was stronger than the signal produced by the chromosome 1 probe and comprised a larger area of the sperm head, making identification of the $\mathrm{Y}$ chromosome easier. However, subjective analysis of the quality of the fluorescence presented by spermatozoa showed that nick translation probes produce a very clear hybridization signal for both chromosomes. Hybridization efficiency was not affected by the sperm treatment and the percentages of spermatozoa with chromosome-1 fluorescent signal were similar for sorted and non-sorted spermatozoa. In both cases this efficiency (number of spermatozoa with the chromosome- 1 signal divided by the number of spermatozoa counted) was near to $98 \%$ (Tables 1 and 2). 


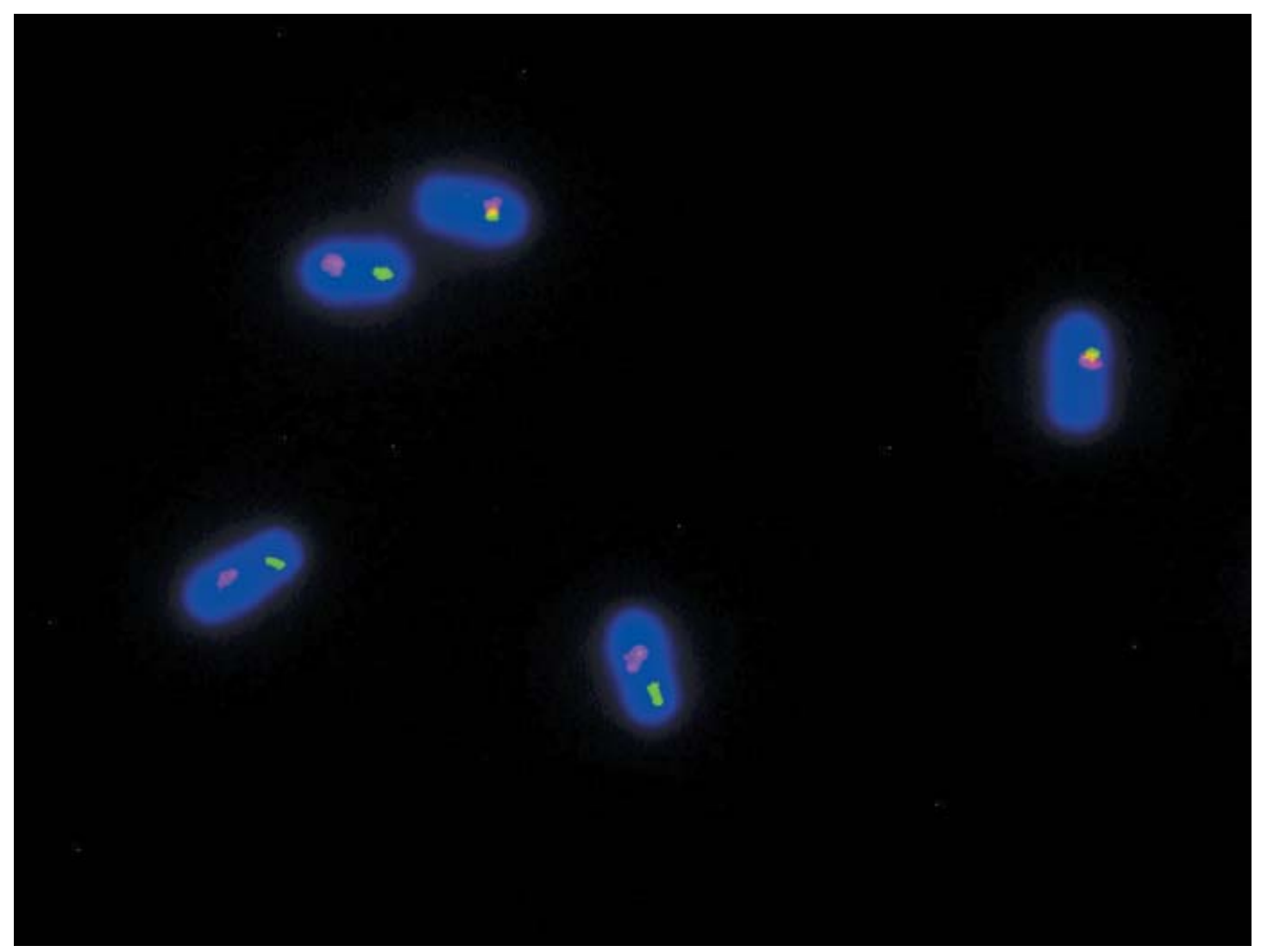

Fig. 3. Sorted boar spermatozoa: 1-chromosome (green signal) and Y-chromosome (red signal) hybridized with nick translation-labelled probes to a Y-sorted sample.

Table 2. Percentage of $\mathrm{X}$ - and $\mathrm{Y}$-chromosome sorted boar spermatozoa by flow cytometry for low and high $\mathrm{Y}$ purity sorting verified by fluorescence in situ hybridization (FISH)

\begin{tabular}{|c|c|c|c|c|c|c|c|c|c|c|}
\hline \multirow[b]{2}{*}{ Boars } & \multicolumn{5}{|c|}{ Sorted spermatozoa for $\mathrm{Y}$ chromosome with low purity (\%) } & \multicolumn{5}{|c|}{ Sorted spermatozoa for $\mathrm{Y}$ chromosome with high purity (\%) } \\
\hline & $\begin{array}{l}\text { Number } \\
\text { counted }\end{array}$ & $\begin{array}{c}\mathrm{Y}(\mathrm{Y} \text { and } 1 \\
\text { signals })\end{array}$ & $\begin{array}{c}\mathrm{X} \text { (only } 1 \\
\text { signal) }\end{array}$ & $\begin{array}{l}\text { Without } \\
\text { signals }\end{array}$ & $\begin{array}{l}\text { Significance } \\
\text { (deviation } \\
\text { from 50:50) }\end{array}$ & $\begin{array}{l}\text { Number } \\
\text { counted }\end{array}$ & $\begin{array}{c}\mathrm{Y}(\mathrm{Y} \text { and } 1 \\
\text { signals })\end{array}$ & $\begin{array}{c}\mathrm{X} \text { (only } 1 \\
\text { signal) }\end{array}$ & $\begin{array}{l}\text { Without } \\
\text { signals }\end{array}$ & $\begin{array}{c}\text { Significance } \\
\text { (deviation } \\
\text { from 50:50) }\end{array}$ \\
\hline A & 200 & 77.5 & 20.5 & 2.0 & $P<0.0001$ & 200 & 92.5 & 6.5 & 1.0 & $P<0.0001$ \\
\hline B & 200 & 74.5 & 27.0 & 2.5 & $P<0.0001$ & 200 & 90.0 & 7.5 & 2.5 & $P<0.0001$ \\
\hline $\mathrm{C}$ & 200 & 75.0 & 22.5 & 2.5 & $P<0.0001$ & 200 & 89.5 & 9.0 & 1.5 & $P<0.0001$ \\
\hline $\mathrm{D}^{*}$ & 200 & 74.0 & 24.0 & 2.0 & $P<0.0001$ & 200 & 93.0 & 5.0 & 2.0 & $P<0.0001$ \\
\hline E & 200 & 71.0 & 27.5 & 1.5 & $P<0.0001$ & 200 & 92.0 & 6.5 & 1.5 & $P<0.0001$ \\
\hline
\end{tabular}

*An additional 10 min decondensation treatment was necessary for this boar.

Spermatozoa showing signal on chromosome-Y but not on chromosome-1 were not observed. Furthermore, the average frequency of aneuploid, probably diploid, spermatozoa was below $0.1 \%$ (spermatozoa showing two red and green signals or two green signals separated by at least one and a half diameter of the respective fluorescence mark within that sperm cell).

Percentages of Y-chromosome-bearing boar spermatozoa were first determined on unsorted samples (Table 1). The Y probe gave a single red signal on approx- imately half of the spermatozoa, which is consistent with half of the spermatozoa carrying a $\mathrm{Y}$ chromosome on unsorted samples (ratio 1:1). Spermatozoa with the fluorescent mark for chromosome 1 (green signal), but without the red signal for Y-chromosome were considered as putative $X$-chromosome-bearing spermatozoa. On flow sorted sperm samples, the red signal was observed on approximately 75 and $93 \%$ of the spermatozoa scored for low and high $\mathrm{Y}$ purity sorting, respectively (Table 2). 
There were no differences at the $P<0.1$ level between the theoretical ratio (50:50) and the observed ratio before sorting, but for boars B and E (Table 1) there was a significant excess of $\mathrm{Y}$-chromosome-bearing spermatozoa at the conventional $P<0.05$ level. However, the percentages of $\mathrm{Y}$-chromosome bearing spermatozoa after sorting were significantly different $(P<0.0001)$ from the 50:50 ratio for both high and low $\mathrm{Y}$ purity sorting.

\section{Discussion}

Evaluating the efficacy of a sorting procedure for the separation of $\mathrm{X}$ - and $\mathrm{Y}$-chromosome-bearing spermatozoa is an important step before using these spermatozoa in reproductive techniques.

FISH has been defined as the most effective method for evaluating sorted spermatozoa as it can be used to examine sperm cells by viewing sperm chromosomes directly (Kawarasaki et al., 1998). The highly qualitative and quantitative independent evaluation is the main advantage of FISH over the use of flow cytometry reanalysis or single cell PCR evaluation.

One of the major problems when FISH is performed on spermatozoa is the extreme degree of condensation of the DNA, making access to specific hybridization sites very difficult. As the time course of sperm decondensation varies considerably among species (Perreault et al., 1988), different decondensation protocols have been established for different species. Nuclei must be decondensed to allow the DNA probes access to the sperm chromatin, but if the nuclei are swollen to more than twice their original size the signal from one chromosome may split and appear as two or more signals, causing the spermatozoa to be falsely scored as disomic (Wyrobèk et al., 1993). Many laboratories have accepted that, for two signals to indicate the labelling of two separate chromosomes, the signals should be separated by at least one-half the size of the signal to ensure they arise from two separate chromosomes and not from a split signal on a single chromosome. Decondensation protocols that have been used successfully on humans do not work well on bovine spermatozoa (Hassanane et al., 1999). A human sperm DNA decondensation protocol (Rousseaux and Chevret, 1995) adapted for boar spermatozoa resulted in spermatozoa with intact morphology of both the head and the tail and allowed efficient double direct FISH to be performed. This protocol is based on treating spermatozoa with dithiothreitol (DTT) to reduce nuclear protamine disulphide bonds and, thereby, accelerating sperm nuclear decondensation. A similar DTT decondensation protocol has been applied by Kawarasaki et al. (1998) on flow-sorted and unsorted boar spermatozoa. Variation among boars was detected in this study with respect to the optimal time for sperm head decondensation. This difference in sperm susceptibility to the decondensation process is dependent on the content in chromatin disulphide bridges of the sperm nuclei (Rodriguez et al., 1985), which is variable between species and also between individuals of the same species, as has been demonstrated.

Rens et al. (2001) performed a FISH experiment on bull spermatozoa sorted by the established Beltsville Sperm Sexing Technology. The result of this study showed that flow sorted cattle spermatozoa were more sensitive than diluted spermatozoa to the decondensation protocol used and that the reagent concentration had to be adjusted to obtain optimal decondensation on the sorted sperm samples. However, our results showed that this procedure for flow cytometric sorting of boar spermatozoa, does not affect nuclear decondensation. Moreover, the accessibility of the probe to the target DNA sequence is not affected by the Hoechst 33342 staining, although this fluorochrome binds tightly to DNA in the minor groove (Johnson and Schulman, 1994). Previous studies in which indirect FISH has been performed on flowsorted boar spermatozoa do not describe any interaction between Hoechst 33342 and specific fluorescent DNA probes (Kawarasaki et al., 1998).

For FISH procedure to be carried out, a direct or indirect fluorescent DNA probe complementary to a specific DNA target sequence is needed. FISH experiments with indirect DNA probes have been performed on different species of domestic mammals to identify sex chromosomes in spermatozoa (Kawarasaki et al., 1995,1996; Hassanane et al., 1999; Piumi et al., 2001; Rens et al., 2001). Although indirect probes are useful for detecting specific DNA sequences, they would perhaps not be the most useful methods for detecting a DNA sequence because their use requires at least one, and usually three, detection steps before visualization under a microscope. Therefore, direct detection is faster and simpler. However it should be noted that direct FISH works only with extremely long targets or with targets consisting of highly repeated short DNA sequences.

The present study used direct DNA probes prepared by nick translation. This method is defined as a homogeneous labelling, owing to the random incorporation of labelled nucleotides throughout the length of the probe. If the reaction is optimally controlled, nick-translated probes can give the highest sensitivity compared with probes labelled by other methods.

The frequency of spermatozoa showing a signal for chromosome 1 was about $98 \%$, demonstrating the high efficiency of the hybridization. Moreover, the results obtained from the high and low purity samples and the unsorted samples showed the efficacy of the probes for determining percentage of $\mathrm{Y}$-chromosome-bearing spermatozoa.

As expected, the highest purity was obtained by narrowing the selection window. The width of the selected sort window is a key factor for obtaining sorted populations of high purity (Johnson, 1997) although at low rates. However, using a wide window it is not possible to produce enough spermatozoa for artificial insemination 
in pigs economically using this method. Additional information about the percentage of aneuploidies for chromosome 1 and $\mathrm{Y}$ was obtained. This percentage was below $0.1 \%$ and is in accordance with the results reported by Rubes et al. (1999).

It was noted in the present study that the nick translation method does not involve extensive manipulation of the samples and, therefore, the risk of contamination is lower than in labelling procedures, such as PCR labelling, which is often used to label DNA probes. However, in the FISH protocol, the labelled DNA fragments are of adequate size to combine with its complementary sequence on sperm heads and, thus, the nick translated DNA fragments yield a clear signal and a clean hybridization. By contrast, with PCR labelling the labelled fragments of DNA may be up $4-5 \mathrm{~kb}$. Because of their size, the fragments do not penetrate the structures surrounding the DNA target and may result only in background hybridization. Additional steps with partial DNase digestion are then necessary to shorten the labelled DNA.

In conclusion, two-colour direct FISH with pig chromosome-specific DNA probes prepared by nick translation provides a useful tool for determining purity on flow cytometry-sorted spermatozoa with a good specificity. The ease of the labelling procedure and the quality of the fluorescent signal obtained demonstrate that nick translation is an ideal labelling method for the preparation of fluorescent pig DNA probes to be used for evaluating flow sorting process on boar spermatozoa. These probes could also be a useful tool in the determination of percentages of chromosomal aneuploidy or other chromosome alterations on pig spermatozoa. Evaluation of the sex of the embryos and the determination of the appropriate development of the embryos are also possible.

This study was supported by grants from European Community (EUREKAEU 1713) and the Spanish Ministry of Science and Technology (CICYT AGL2001-0471). The authors would like to thank W. V. Holt for a critical read of the manuscript; the authors also thank G. Webb for suggesting amendments to the manuscript.

\section{References}

Di Berardino D, Jovino V, Lioi MB, Scarfi MR and Burguete I (1996) Spontaneous rate of sister chromatid exchanges (SCEs) and BrdU doseresponse relationships in mitotic chromosomes of goat (Capra hircus L.) Hereditas 124 137-143

Fugger EF, Black SH, Keyvanfar K and Schulman JD (1998) Births of normal daughters after MicroSort sperm separation and intrauterine insemination, in vitro fertilization, or intracytoplasmic sperm injection Human Reproduction 13 2367-2370

Hassanane M, Kovacs A, Laurent P, Lindblad K and Gustavsson I (1999) Simultaneous detection of $\mathrm{X}$ - and $\mathrm{Y}$-bearing bull spermatozoa by double colour fluorescence in situ hybridization Molecular Reproduction and Development 53 407-412

Jantsch M (1989) Sus scrofa Mc1 satellite DNA. National Center for Biotechnology Information. X12696
Johnson LA (1991) Sex preselection in swine: altered sex ratios in offspring following surgical insemination of flow sorted X- or Y-bearing sperm Reproduction in Domestic Animals 26 309-314

Johnson LA (1997) Advances in gender preselection in swine Journal of Reproduction and Fertility Supplement 52 255-266

Johnson LA and Pinkel D (1986) Modification of a laser-based flow cytometer for high resolution DNA analysis of mammalian spermatozoa Cytometry 7 268-273

Johnson LA and Schulman JD (1994) The safety of sperm selection by flow cytometry Human Reproduction 9 758-759

Johnson LA and Welch GR (1999) Sex preselection: high-speed flow cytometry sorting of $X$ and $Y$ sperm for maximum efficiency Theriogenology 52 1323-1341

Johnson LA, Flook JP and Look MV (1987) Flow analysis of X- and Ychromosome-bearing sperm for DNA using an improved preparation method and staining with Hoechst 33342 Gamete Research 17 203212

Johnson LA, Aalbers JG and Grooten HJG (1988) Artificial insemination of swine: fecundity of boar semen stored in beltsville TS (BTS), modified modena (MM) or MR-A and inseminated on one, three and four days after collection Zuchthyg 23 49-55

Johnson LA, Flook JP and Hawk HW (1989) Sex preselection in rabbits: live births from X-and Y-sperm separated by DNA and cell sorting Biology of Reproduction $4 \mathbf{1}$ 199-203

Johnson LA, Welch GR, Keyvanfar K, Dorfmann A, Fugger EF and Schulman JD (1993) Gender preselection in humans? Flow cytometric separation of $X$ and $Y$ spermatozoa for the prevention of $X$-linked diseases Human Reproduction 8 1733-1739

Kawarasaki T, Kohsaka T, Sone M, Yoshida M and Bamba K (1995) Detection of $\mathrm{Y}$-bearing porcine spermatozoa by in situ hybridization using digoxigenin-labeled, porcine male-specific DNA probe produced by polymerase chain reaction Molecular Reproduction and Development 40 455-459

Kawarasaki T, Sone M, Yoshida M and Bamba K (1996) Rapid and simultaneous detection of chromosome $\mathrm{Y}$ - and 1-bearing porcine spermatozoa by fluorescence in situ hybridization Molecular Reproduction and Development 43 548-553

Kawarasaki T, Welch GR, Long CR, Yoshida M and Johnson LA (1998) Verification of flow cytometorically-sorted $\mathrm{X}$-and Y-bearing porcine spermatozoa and reanalysis of spermatozoa for DNA content using the fluorescence in situ hybridization (FISH) technique Theriogenology $\mathbf{5 0}$ 625-635

Langer PR, Waldrop AA and Ward DC (1981) Enzymatic synthesis of biotinlabeled polynucleotides: novel nucleic affinity probes Proceedings National Academy of Sciences USA 78 6633-6637

McGraw RA, Jacobson RJ and Akamatsu M (1988) A male-specific repeated DNA sequence in the domestic pig Nucleic Acids Research 1610389 (Abstract)

Perreault SD, Barbee RR, Elstein KH, Zucker RM and Keefer CL (1988) Interspecies differences in the stability of mammalian sperm nuclei assessed in vivo by sperm microinjection and in vitro by flow cytometry Biology of Reproduction 39 157-167

Piumi F, Vaiman D, Cribiu EP, Guerin B and Humblot P (2001) Specific cytogenetic labeling of bovine spermatozoa bearing $\mathrm{X}$ or $\mathrm{Y}$ chromosome using fluorescent in situ hybridization (FISH) Genetic Selection Evolution 33 89-98

Rens W, Yang F, Welch G, Revell S, O'Brien PCM, Solanky N, Johnson LA and Ferguson Smith MA (2001) An X-Y paint set and sperm FISH protocol that can be used for validation of cattle sperm separation procedures Reproduction 121 541-546

Rigby PW, Dieckmann M, Rhodes C and Berg P (1977) Labelling deoxyribonucleic acid to high specific activity in vitro by nick translation with DNA polymerase I Journal of Molecular Biology 113237 251

Rodriguez H, Ohanian C and Bustos-Obregon E (1985) Nuclear chromatin decondensation of spermatozoa in vitro: a method for evaluating the fertilizing ability of ovine semen International Journal of Andrology 8 $147-158$ 
Rousseaux S and Chevret E (1995) In vitro decondensation of human spermatozoa for fluorescence in situ hybridisation Human Reproduction 10 2209-2213

Rubeš J, Vozdová M and Kubìcková S (1999) Aneuploidy in pig sperm: multicolor fluorescence in situ hybridization using probes for chromosomes 1, 10, and Y Cytogenetics and Cell Genetics 85 200-204

Seidel GE and Garner DL (2002) Current status of sexing mammalian spermatozoa Reproduction 124 733-743

Vazquez JM, Martinez EA, Parrilla I, Roca J, Gil MA and Vazquez JL (2003) Birth of piglets after deep intrauterine insemination with flow cytometrically sorted spermatozoa Theriogenology 59 16051614

Welch GR and Johnson LA (1999) Sex preselection: laboratory validation of the sperm sex ratio of flow sorted X- and Y-sperm by sort reanalysis for DNA Theriogenology 52 1343-1352
Welch GR, Waldbieser GC, Wall RJ and Johnson LA (1995) Flow cytometric sperm sorting and PCR to confirm separation of X-and Y-bearing bovine sperm Animal Biotechnology 6 131-139

Wyrobèk AJ, Robbing WA, Tang C, Kobayashi A, Baulch J, Weier H-U and Pinkel D (1993) Hierarchical organization of human sperm chromatin is critical factor in the detection of chromosomal aneuploidies by fluorescence in situ hybridization American Journal of Human Genetics Supplement 53 130a (Abstract)

Received 21 November 2002.

First decision 13 January 2003.

Revised manuscript received 24 April 2003.

Accepted 1 May 2003. 